\title{
The Changing Structure of the Cement Industry of India
}

\author{
Dr Manoj K Sharma \\ Professor \\ University Business School \\ Panjab University \\ Chandigarh \\ Arpit Khurana \\ Assistant Professor \\ Institute of Management \\ DAV College, Chandigarh
}

\section{Introduction}

\subsection{Indian Cement Industry}

Today, the Indian cement industry is 103 years old and now it has 94 major cement companies, which have 253 modern cement plants with an aggregate cement capacity of about 5000 MTPA. With this, Indian is the second largest cement producer in the world, the first being China.

At present, the Indian cement industry is spread all over the country, from north to south and east to west with the most modern cement plants having latest energy efficient technologies. The country has 94 major cement companies, which operate 253 modern cement plants, comprising integrated, grinding, and exclusive clinker plants. They have an aggregate cement capacity of about 500 million tonnes per annum (MTPA) along with captive power plants of 4516 MW and waste heat recovery power plants of $357.06 \mathrm{MW}$. Besides, there are also about 300 mini and tiny cement plants, which have an estimated capacity of about 10 MTPA.

\subsection{ORIGIN}

The first ever reference of cement production in India is recorded in George Watt's Directory of 'Economic' Products of India,' published in 1889, which stated; "Portland cement was being made in Calcutta from argillaceous kanker". However, the first organised attempt of manufacture the cement was made in 1904 by the Madras-based South India Industries Limited but this venture failed. It was in October 1914 that the cement produced at Porbandar in Gujarat by the Indian Cement Corporation Limited saw the light of the day. It had an installed capacity of a mere 1000 tonnes per annum. In the next two years, the Katni Cement Limited and Bundi Portland Cement Limited set up their cement plants at Katni in Madhya Pradesh in 1915; and at Lakheri in Rajasthan in 1916, respectively, By 1918, these three cement companies together churned out 85,000 tonnes of cement per annum.

Between 1919 and 1924, six more plants were set up and the capacities of three old plants were also expanded. By the end of 1924, the strength of cement plants rose to 10 with a total installed capacity of 0.56 MTPA. In those years, the actual production was well below 50 per cent of the capacity, which ironically, still surpassed the demand. This resulted in selling of cement below the production cost. Further, the scepticism of quality of indigenous cement only compounded the problems of the industry. This led to liquidation of some companies. At this point of time, the government referred the functioning of cement industry to Tariff Board.

During the World War II, the control was imposed on price and distribution of cement for the first time. And in August 1942, the cement for the first time. And in August 1942, the cement was declared as an essential commodity under the Defence of India Rules. About 90 per cent of the total production was acquired for defence use. The price was fixed on cost plus basis. As government needs decreased towards the end of the War, the surplus stocks were released for civilian consumption at fixed prices.

\subsection{POST-INDEPENDENCE GROWTH-}

At the time of India's partition in 1947, there were 23 cement plants in operation with a total capacity of 2.2 MTPA. With the partition, 18 cement plants remained in India and five plants went to Pakistan. The plants, which remained in India, had an aggregate cement capacity of 1.47 MTPA. Simultaneously, the British Standards for cement were replaced by Bureau of Indian Standard (BIS) specifications. 
Beset upon the task of rendering better standards of living for its people, the new government gave top priority to food and shelter programmes. The cement was needed the most. As a sequel, in the first five-year plan, 1951-56, the government fixed the capacity and production targets for cement industry at 5.02 MTPA and 4.60 MTPA, respectively. By the end of this plan in 1956, there were 27 cement units with a capacity of 5 MTPA and the production was 4.6 million tonnes. During the second five-year plan, 1956-61, the number of units went up from 27 to 34; the capacity increased from 5 MTPA to 9.3 MTPA, and the actual production soared from 4.6 million tonnes to 8 million tonnes. The new types of cements like white cement and Portland Slag Cement (PSC) were also manufactured during this plan period. Cement industry growth through five-year plans were shown in the table No. 1.

\subsection{S-THE DECADE OF GROWTH}

The decade of 90's was a decade of growth and consolidation for the Indian cement industry through new capacity addition, maximum acquisitions, and mergers. The years between 1994 and 1999 saw a 40 MTPA new capacity addition. This rash growth led to supplies being much in excess of demand, leading to prices being constantly beaten down. The fact that this imbalance took place even while demand grew at a healthy 8 per cent, illustrated the seriousness of the problem. Not surprisingly, bottom lines throughout the industry were affected.

The financially weak companies sold out their units to those looking to consolidate. This decade witnessed the acquisitions and mergers of about 20 companies were. In contrast, the year of 1999-2000, offered much to cheer about. The demand grew by a whopping 15 per cent, while a new capacity of a mere 2 MTPA was added.State-wise plants and their capacity are shown in the Table No. 2.

\subsubsection{9-ENTRY OF CEMENT MNCS}

The year of 1999 was a mute witness to the entry of cement multinational companies (NNCs) in India starting with Lafarge. The Paris-based Lafarge commenced its Indian operations in November 1999 by acquiring Tata Steel's two cement plants-Jojobera in Jharkand and Sonadih in Chhattisgarh, with a combined capacity of 1.7 MTPA for Rs 550 crore.

After Lafarge's entry, six more cement MNCs had entered in India's cement sector through acquisitions and also by making strategic investments in this existing cement companies. These global acquired the Italcementi of Italy in 2000; Holcim of Switzerland in 2005; Heidelberg of Germany in 2006; Cimpor of Portugal in 2007; Vicat SA of France in 2008; and CRH of Ireland in 2008. However, Cimpor quit India in 2013 and it was replaced by VotorantimCimentos. In 2015, Lafarge and Holcim merged globally to form Lafarge Holcim, while Heidelberg Cement AG fully acquired the Italcementi. These global changes also impacted similarly their Indian subsidiaries, namely: Lafarge India Private Limited, Ambuja Cement Limited, ACC Limited, and Zuari Cements Limited. The first three companies became a part of Lafarge Holcim, while the Italcementi owned subsidiary-Zuari Cements Limited became an integral part of Heidelberg Cement Indian Limited.

The period of 2011-2014 has been comparatively a challenging time for the Indian cement industry owing to the economic slowdown, excess production capacity and sluggish demand. Though this didn't dither the expansion plans of cement companies and they have set up high capacity integrated plants, more number of grinding units, increased the use of fly ash and slag in cement manufacturing, increased use of pet coke and varieties of wastes, established coal based captive power plants, and waste heat recovery power plants.

\subsection{MAJOR CONSOLIDATION: 2015-17}

However, the last three years of 2015 to 2017, have witnessed a major consolidation in Indian cement industry. Ultra Tech Cement Limited acquired 11 cement plants with 21.2 MTPA from Jaypee Group; and Orient Cement Limited too bought out three cement plants from Jaypee Group with a capacity of 4.2 MTPA. Consequently, Jaypee Group, which was the third largest cement producer in the country, lost its status and now it is pushed down to $19^{\text {th }}$ position among the top 25 cement companies in India. The list of top 25 cement companies according to their capacity are presented in table No. 3.

\section{Literature Review}

Appropriate techniques for measuring market concentration and its effects had developed, initially in the field of industrial economics in the USA, UK and particularly other developed countries. Curry and George (1983) provide an extensive survey of such research. Measuring the extent of market concentration in banking is of interest in its own right. The initial study on concentration and competition in banking was done by Alhadeff (1980). The studies generally examine concentration issues in the context of overall Structure-Conduct-Performance relationship (SCP).SCP suggests that higher concentration leads to higher prices which lead to higher financial returns. 
Berger and Hannan (1989) Positive correlations between market concentration and profitability can be explained by the structure performance hypothesis or the efficient structure hypothesis. The study use price information collected by the Federal system on banking institutions to examined prince-concentration relationships instead of the profit concentration. The results of this analysis supported the structure performance relationship.

Jefferson and Wenyi (1991) study investigated the degree to which socialist enterprises in transition mimic the behaviour of the canonical neoclassical firm. The study gave evidence of increasing a locative efficiency as measured by patterns of factor return equalization and rapid capacity growth among the most profitable enterprise.

Hannan (1991) paper employs an explicit model of the banking firm to derive formally the structure-conductperformance paradigm as it applies to the banking industry. The necessary assumption and simplifications implicit in past empirical studies were outlined and suggestions for future empirical implementation of the underlying mode were presented in a systematic way.

Schumacher (1991) in his pioneer work studied the relationship between performance and market structure, with particular emphasis on the organization of the market on the buyer's side and its effect on seller profit margins. The study took stratified sample of U.S. manufacturing industries. The study established that highly concentrated buyers exhibit significant power to impair profitability especially in oligopolistic consumer goods industries. The impact of countervailing power appears to be strong regardless of demand conditions. They summed up their findings that the countervailing power argument appears to hold regardless of the state of demand faced by the selling industries for the contention that buyer power and its detrimental effect on sellers profit rates would be enhanced under weak demand conditions cannot stand up to empirical testing.

Alley (1993) tested the hypothesis that Japanese banking performance is a result of efficiency structure hypothesis instead of the SCP hypothesis. In the model he estimated the high and significant degree of collusion in the Japanese banking industry. The finding of his analysis supports the structure conduct performance hypothesis as a best way of describing the Japanese banking industry.

Caroll (1993) examined the relationship between market structure and performance for the U.S. workers' compensation insurance using data for the period 1980-1987. She tested SCP and efficient structure hypothesis. Research results found no support for either tested hypothesis.

Williams et al (1994)examinedtwo competing hypotheses with regard to market structure and performance are the traditional structure-conduct-performance (SCP) paradigm and the efficiency hypothesis. The results generally support the traditional SCP paradigm as an explanation for the market behaviour of Spanish banks and this suggests that further concentration in the Spanish banking market, currently being encouraged by the government and the Bank of Spain, is likely to unambiguously decrease the level of competition in the system and cannot be justified on efficiency grounds.

Lui, Sun, Kaiser (1995) analysed the degree of market power exercised by fluid and manufactured processors in the U.S. dairy industry in Appelbaum's quantity setting conjectural variation approach is cast into a switching regime framework to account for the two market regimes created by the existence of the dairy price support program..). The results also indicated that manufactured and fluid processors tend to behave in a more competitive manner in the market equilibrium regime than in the government supported regime market conduct.

Tholkapian (1998) studied the impact of competition among foreign and Indian firms on basis of structure and performance of domestic industries during the post-reforms period using the SCP paradigm. He analyzed the SCP relationships using firm level data pertaining to 25 manufacturing industries in India during the year 1992-93. He found that market concentration is significantly explained by firm conduct and market performance. Moreover, Market concentration also has a positive relationship with profitability of foreign firm, while it is negatively related to profitability of Indian firms. The study also finds that foreign firms may enjoy higher profits at the expense of Indian firms.

Nanyang (2003) studied the basic SCP Framework to analyse the media industry in Singapore. The study restated the constructs and premises of the SCP model, and the orthodox economic notions of market performance. The study also discussed conceptualizations and interpretations normally found in media market research studies. Media content diversity and media concentration, which are often studied through the SCP approach, were also reexamined. It further identified and addressed common misconception to study the media industry and expounded how utilization of the model can be enhanced.

Krishnan and Narayankumar (2010) This paper has examined the structure, conduct and performance of the value chain in seaweed farming in India inquiring into the production, institutional, marketing, social and community relationships in small-scale seaweed farming. The SHG model has also shown strong gender orientation in the initial years of seaweed culture in the district contributing to strong structure foundations to the movement. 
Fosu (2013) This paper examines the extent of banking concentration in African sub regional markets. A dynamic version of the Panzar-Rosse model is adopted beside the static model to assess the overall extent of banking competition in each sub-regional banking market. Consistent with other emerging economies, the results suggest that African banks generally demonstrate monopolistic competitive behaviour.

Laibuni and Omiti (2014) this study seeks to examine recent trends in domestic lrish potato prices in the production market. Its and investigate the relationship between market concentration and price of Irish potato in the different market. The results show that there is a general rise in the price of potatoes. Potato markets are oligopolistic in nature; a few market participants in the form of rural brokers, urban brokers and transporters have the market power. There are barriers to entry at the urban market center where brokers provide the link between wholesalers and retailers. In many cases, brokers and transporters determine the market price for each potato consignment.

\section{Database and Methodology}

3.1. The major cement companies were chosen based on the market share in an interval of five years from 19982002,2003-2007,2008-2012,2013-2017. The sales revenue of these companies is shown in the table no. 4, 5, 6, 7 respectively.

The TableNo.4 shows the sales revenue of major 31 cement companies that were prominent

Duringthe period 1998 to 2002. The sales figures are in Rs Million.

The Table No. 5 shows the sales revenue of major 38 cement companies that were prominent during the period 2003 to 2007. The sales figures are in Rs Million.

The following Table No.6 shows the sales revenue of major 44 cement companies that were prominentduring the period 2008 to 2012. The sales figures are in Rs Million.

The Table No.7 shows the sales revenue of major 54 cement companies that were prominent during the period 2013 to 2017. The sales figures are in Rs Million.

\subsection{Changing Pattern of Market Concentration in Cement Industry}

Concentration is an important aspect of the structure of any industry. Evidence suggests that an industry's conduct and performance is deeply influenced by the degree of concentration.

In the study five concentration indices have been used to calculate the market concentration of the Indian cement industry. These are the firm Concentration Ratio (CR); The Herfindahl-Hirschman Index (HHI); The Hall-Tideman Index (HTI); The Comprehensive Industrial Concentration Index (CCI); and The Entropy measure (E).

A. Concentration Ratio (CR):This index, which is preferred thanks to its simplicity and less datarequirement, is defined as the sum of the market shares of the first $\mathrm{k}$ firms with the largest share in the market. Although the choice of the value of the $\mathrm{k}$ parameter depends on the researchers, it is usually taken as $\mathrm{k}=3$, and $\mathrm{k}=5$ in empirical applications. The index takes a value between 0 (= perfect competition) and 1 (= monopoly) and is mathematically expressed in Equation 2:

$$
C R_{\mathrm{k}}=\Sigma s i
$$

B.Herfindahl Hirschman Index (HHI): One of the most popular concentration indices, HHI Index iscalculated by summing the squares of the market shares of all firms in the market and it is formulated as in Equation 3: The HHI index takes a value between $1 / \mathrm{n}$ and 1 and index reaches the unity in the case of monopoly. The market structure can be determined as low, moderate, high concentrated according to the value of HHI index. ${ }^{2}$ The HHI index is more consistent than the CR because it gives less weight to small firms while giving more weight to larger firms and covers all firms on the market. Davies (1979) analyzed the sensitivity of the HHI to its two parts, which are the number of firms in the market and the the inequality in market shares among the different firms. He found that the index becomes less sensitive to changes in the number of firms the larger the number of firms in the industry.

\section{$H H I=\Sigma s i$}

C.Hall-Tideman (1967) Index (HTI):This index was first used by Hall \&Tideman (1967) and theauthors have argued that the number of firms should be taken into account when calculating the concentration index. They calculated the HTI index by ordering companies from large to small, and numbering each company ( $\mathrm{i}=1$ for the largest firm). HTI takes a value between $1 / \mathrm{n}$ and 1 and if there is an infinite number of companies in the same denominator it approaches to zero, whereas in monopoly it approaches to 1 .

$$
H T I=1[(2 \Sigma i s i) n i=1-1]
$$

D.The Comprehensive Industrial Concentration Index (CCI):Hovarh (1970) emphasized that theproblem of concentration and dispersion is important when determining the market structure. In the study, the author calculated CCI index for companies with different distributions through the following Equation 5 below. 
In the CCI, which receives the theoretical form from HHI, s1 refers the market share of the leading company, the rest of the equation represents the sum of squares of each company's share weighted by $(1+(1-s i))$.

This last component decreases the effect of Herfindahl's geometric progression. Moreover, the purpose of this component to strengthen the capacity of CCI is not only to rank orders but also to mirror absolute features (Hovarth, 1970). While the CCI takes 1 in the monopoly case, it decreases to 0 in the perfect competition.

$$
C C I=s 1+\Sigma s i 2(1+(1-s i))
$$

E.Entropy (E): The use of this Entropy term, which is borrowed from the theory of physics and information, as a concentration index was first discussed by M.O. Finkelstein \& R.M. Friedberg (1967) and then was used in the study of Stigler (1964) and Marfels (1972) (Hause, 1977). The entropy index takes a value between 0 and $\log 2 n$, and there is an inverse relationship between the index value and the degree of concentration.

The Entropy as a measure of concentration has been presented in this article on the basis of a logarithm with base 2, as proposed by White (1982) (Biker \&Haaf, 2002).

$$
E=-\Sigma s i \log 2 s i
$$

\subsection{Concentration Ratios (CR3, CR5 \& CR10)}

The concentration ratio of three firms, five firms and ten firms are shown in the Figure No. 1. It shows that value of CR3 in 1998 was .3684 and it remains almost same up tothe year 2003 and after which it declines to 3426 in 2005 . The major decline was observed in 2010 i.e..3036 which explains that market becomesnoticably competitive in 2010.After which some mergers and acquisitions take place and the value rises to.367 in 2011 and again it shows decline in the concentrationas CR3 reaches to.3343 in 2017. The similar kind of behaviour was observed by the five-concentration ratio. Its value is .4893 in 1998 and a major decline was in $2010($ CR5 $=.4298)$ and then again shows a gradual decline from 2011 till 2017. The ten-concentration ratio (CR10) was .7598 in 1998, thus top 10 firms contribute to more than $75 \%$ share of Indian Cement Industry. After which the market becomes more concentrated and this value rises to .7953 in 2001.Thus almost $80 \%$ of the share is being held by the major ten firms. Thus, the market can be called as Monopolistic Competition. But after this the value starts declining and it reaches to .6549 in 2017, thus it starts moving towards competitive market as it approaches 2017. Thus the Concentration Ratio clearly depicts that the market competition has increased in 2017.

\subsection{Herfindahl Hirschman Index (HHI)}

The HHI used to calculate the concentration of the Indian cement industry is shown in the Figure No.2. Its value is 848.05 in the year 1998, after which it starts inclining and reaches the value of 934.68 thus showing the industry is getting concentrated when it reaches the year 2002. But after this the industry experienced a sharp decline as HHI value decreased to 792.62 in the year 2003 and it decreases further. The major decline that the cement industry experienced in the year 2010 when the value of HHI reaches 629.27. The industry saw various ups and downs in the market concentration during the last 20 years but in the whole the industry moves towards the competitive market as it moves from 1998 to 2017.

\subsection{The Comprehensive Industrial Concentration Index (CCI)}

The Comprehensive Industrial Concentration Index (CCI) used to calculate the cement industry concentration is shown in the Figure No. 3. Its value is .2779 in the year 1998 and after which it increases continuously up to the year 2001, thus showing the industry is getting concentrated.But 2001 onwards the value of CCI goes decreasing. The sharpest decline was observed in the year 2010 showing the increase in the competitive ness of the Indian cement Industry. The CCI shows stable values during the corresponding 20 years. Only in the year 2006 and 2010, major variation in the values of CCI were observed but on the whole the concentration of the cement industry did not change noticeably from 1998 to 2017.Thus, the industry remains competitive in all these years.

\subsection{Hall-Tideman (1967) Index (HTI)}

The Hall-Tideman Index (HTI)) used to calculate the cement industry concentration is shown in the Figure No. 4.Its value is .0543 in the year 1998, .0539 in the year 1999 and similar values were observed throughout the time period. HTI value reaches to .04736 in the year 2017.This shows that the industry did not change drastically from 1998 to 2017 but some level of competitiveness has increased during the studied time period.

\subsection{Entropy}

The Entropy values used to calculate the concentration of cement industry is shown in the Figure No. 5. The Entropy value was 4.56 in the year 1998, after which it starts increasing showing the increase in competitiveness of the industry. But again, the major decline was observed in the year 2007 and 2011, after which it rises again. 
On the whole, the Entropy values show some upward and downward trends and value rises to 4.75 in the year 2017, thus there is an increase in level of competition as it moves from 1998 to 2017.

\section{Conclusion}

The paper examined the nature and the extent of changes in the market concentration in the Indian cement industry and their competitiveness over a period of 20 years. In contrast to earlier studies on the market structure of industry, this paper focused on both absolute and relative measures of market concentration of Indian cement industry. The paper found strong evidence of change in market structure of cement industry in India. One of the important results obtained from the study regarding the market structure of the Indian cement industry between 1998 and 2017 using the market concentration indices such as the $\mathrm{k}$ firm Concentration Ratio (CRk); the Herfindahl-Hirschman Index (HHI); the HallTideman Index (HTI); the Comprehensive Industrial Concentration Index (CCI) and the Entropy measure (E); is that the market has a low concentration during the corresponding period.

The study presents all the concentration indices results for the Indian cement industry for 1998-2017 period. When looking at the CR and HHI, which are frequently used in the literature in the market structure and accepted by the official institutions of the countries, it is seen that both indices have been increasing first and then start decreasing during the period. The decline in these indexes gives us the knowledge that competition in the market is increasing. The evidence of growing competitive pressure was also well supported by the declining trend of HHI as it declined from 678.6997 in 1998 to 632.6515 in 2017.

When looking at HTI index, which focuses on the number of firms in the cement industry and the largest firm in the market, it can be said that the index value has decreased from 0.054 to 0.047 and the competitive structure has increased.

When CCI and Entropy indices are examined, it can be said that the Indian cement industry sector has a competitive structure in 1998-2017 period, consistent with other indices. However, unlike the CRk, HHI, HTI and Entropy indices, the competitive structure of the market has changed less. While CCI index shows that there is no significant change in the market structure, considering that CCI is a more effective measure in the market for cartel features, it can be said that the CCI is not sufficient to determine the changes in Indian cement market structure.

Applied in practice, the various concentration measures may show strongly diverging values for the same market, owing to the use of varying weighting schemes, which reflect mainly different assessment regarding the relative impact of larger and smaller firms on competition in a certain market. Policy makers can select suitable concentration indices depending on (i) the features of their suitable market (ii) their perceptions regarding the relative impact larger and smaller firms have on competition in a certain market, and (iii) their perceptions regarding the relative impact of size distribution and number of firms (for instance, reflecting the impact of a new entry).

\section{List of Tables \& Figures}

Table 1: Cement Industry's Growth Though Five-Year Plans

\begin{tabular}{|l|l|l|l|l|}
\hline Five Year Plans & Plans' Period & Terminal Year & Capacity MTPA & $\begin{array}{l}\text { Production } \\
\text { tonnes }\end{array}$ \\
\hline Pre Plan & $1950-51$ & 1951 & 3.28 & 2.20 \\
\hline Ist Plan & $1951-56$ & 1956 & 5.02 & 4.60 \\
\hline IInd Plan & $1956-61$ & 1961 & 9.30 & 7.97 \\
\hline IIIrd Plan & $1961-66$ & 1966 & 12.00 & 10.97 \\
\hline IVth Plan & $1969-74$ & 1974 & 19.76 & 14.66 \\
\hline Vth Plan & $1974-79$ & 1979 & 22.58 & 19.42 \\
\hline VIth Plan & $1980-85$ & 1985 & 42.40 & 30.13 \\
\hline VIIth Plan & $1985-90$ & 1990 & 61.31 & 45.41 \\
\hline VIIIth Plan & $1992-97$ & 1997 & 105.26 & 76.22 \\
\hline IXth Plan & $1997-02$ & 2002 & 146.13 & 108.40 \\
\hline Xth Plan & $2002-07$ & 2007 & 202.64 & 165.56 \\
\hline XIth Plan & $2007-12$ & 2012 & 298.00 & ----- \\
\hline XIIth Plan & $2012-17$ & 2017 & 479.30 & 407.40 \\
\hline
\end{tabular}

MTPA - Million Tonnes Per Annum, Mn Tonnes - Million Tonnes

Source: Survey of Cement Industry \& Directory 2019, 6th Edition 
Table 2: State wise Major Cement Plants with their Capacities at a Glance -2017 (alphabetically listed)

\begin{tabular}{|l|l|l|l|l|}
\hline Nos & States & No. of Plants 2017 & Capacity MTPA 2017 & Percentage of capacity MTPA 2017 \\
\hline 1 & Andhra Pradesh & 28 & 58.24 & 11.60 \\
\hline 2 & Assam & 6 & 5.27 & 1.05 \\
\hline 3 & Bihar & 5 & 8.7 & 1.73 \\
\hline 4 & Chhattisgarh & 12 & 26.35 & 5.25 \\
\hline 5 & Gujarat & 17 & 38.76 & 7.72 \\
\hline 6 & Haryana & 5 & 7.2 & 1.43 \\
\hline 7 & Himachal & 7 & 12.75 & 2.54 \\
\hline 8 & Jammu \& Kashmir & 3 & .83 & .12 \\
\hline 9 & Jharkhand & 5 & 10.25 & 2.04 \\
\hline 10 & Karnataka & 16 & 46.24 & 9.21 \\
\hline 11 & Kerala & 2 & .86 & 0.17 \\
\hline 12 & Madhya Pradesh & 12 & 35.22 & 7.02 \\
\hline 13 & Maharashtra & 13 & 32.18 & 6.41 \\
\hline 14 & Meghalaya & 9 & 9.63 & 1.92 \\
\hline 15 & Odisha & 4 & 10.45 & 2.08 \\
\hline 16 & Punjab & 4 & 6.57 & 1.31 \\
\hline 17 & Rajasthan & 23 & 67.28 & 13.41 \\
\hline 18 & Tamil Nadu & 21 & 41.58 & 8.29 \\
\hline 19 & Telangana & 19 & 30.13 & 6.00 \\
\hline 20 & Uttar Pradesh & 17 & 27.58 & 5.50 \\
\hline 21 & Uttarakhand & 3 & 3.9 & 0.78 \\
\hline 22 & West Bengal & 16 & 21.89 & 4.36 \\
\hline & Total & 247 & 501.86 & \\
\hline
\end{tabular}

MTPA - Million Tonnes per Annum

Source: Survey of Cement Industry \& Directory 2019, 6th Edition

Table 3: Capacity-wise India's Top 25 Cement Groups/ Companies

\begin{tabular}{|c|c|c|c|c|}
\hline Rank & Cement Groups/ companies & $\begin{array}{l}\text { No of Cement } \\
\text { Plants }\end{array}$ & $\begin{array}{ll}\text { Capacity } & \text { MTPA } \\
2017 & \end{array}$ & $\begin{array}{l}\text { Percentage } \\
\text { of MTPA } \\
2017(\%)\end{array}$ \\
\hline 1 & Ultratech Cement & 39 & 89.40 & 20.89 \\
\hline 2 & Lafarge Holcim India (ACC+Ambuja) & 28 & 63.06 & 14.74 \\
\hline 3 & Shree cement & 10 & 27.20 & 6.36 \\
\hline 4 & Dalmia Bharat + Four Subsdiaries & 11 & 24.92 & 5.82 \\
\hline 5 & Ramco Cements & 09 & 16.49 & 3.85 \\
\hline 6 & India Cements & 10 & 15.55 & 3.63 \\
\hline 7 & Chettinad + Anjani & 05 & 15.40 & 3.60 \\
\hline 8 & Birla Corp + RCCPL & 07 & 15.30 & 3.58 \\
\hline 9 & Nirma + Nuvco Vistas & 06 & 13.33 & 3.11 \\
\hline 10 & Century Textiles \& Industries & 04 & 12.80 & 2.99 \\
\hline 11 & JK Lakshmi + UCWL & 06 & 12.60 & 2.94 \\
\hline 12 & Heidelberg + Zuari & 07 & 12.31 & 2.88 \\
\hline 13 & Orient + BJCL + JPVL & 06 & 12.20 & 2.85 \\
\hline 14 & JSW Cement & 04 & 11.40 & 2.66 \\
\hline 15 & Kesoram Industries & 02 & 10.75 & 2.51 \\
\hline 16 & JK cement & 05 & 10.50 & 2.45 \\
\hline 17 & My Home Industries +SJCL & 04 & 10.00 & 2.34 \\
\hline 18 & Penna Cement + PCIL & 05 & 08.70 & 2.03 \\
\hline 19 & Jaiprakash Associates + JCCL & 05 & 08.30 & 1.94 \\
\hline 20 & Vicat India (Bharathi + Kalburgi) & 02 & 07.75 & 1.81 \\
\hline 21 & Wonder cement & 01 & 06.75 & 1.58 \\
\hline 22 & Prism Cement & 01 & 06.60 & 1.54 \\
\hline 23 & Binani Cement & 02 & 06.25 & 1.46 \\
\hline 24 & Vadraj Cement (ABG) & 01 & 06.00 & 1.40 \\
\hline \multirow[t]{2}{*}{25} & Emami Cement & 02 & 04.40 & 1.03 \\
\hline & Total & 182 & 427.96 & 100 \\
\hline
\end{tabular}

Source: Survey of Cement Industry \& Directory 2019, 6th Edition 
Table 4: Sales Revenue from 1998 to 2002

\begin{tabular}{|c|c|c|c|c|c|c|}
\hline Sr. No. & Major cement firms from 1998 to 2002 & \begin{tabular}{|l|}
1998 \\
(Rs Mn) \\
\end{tabular} & \begin{tabular}{|l|}
1999 \\
(Rs Mn) \\
\end{tabular} & $\begin{array}{l}2000 \\
\text { (Rs Mn) }\end{array}$ & $\begin{array}{l}2001 \\
\text { (Rs Mn) }\end{array}$ & \begin{tabular}{|l|}
2002 \\
(Rs Mn) \\
\end{tabular} \\
\hline 1 & A C C Ltd. & 23731.1 & 25858.3 & 26792.2 & 29361.2 & 32260 \\
\hline 2 & Ambuja Cements Ltd. & 11457.8 & 12523.4 & 13027.8 & 14473.2 & 15826.3 \\
\hline 3 & Andhra Cements Ltd. & 1864.4 & 1206.6 & 1288.4 & 1665.7 & 1956.7 \\
\hline 4 & Birla Corporation Ltd. & 9449.8 & 8445.5 & 9504.1 & 9679.9 & 10623.7 \\
\hline 5 & Cement Corpn. Of India Ltd. & 2374.3 & 2118.1 & 1412.4 & 756.9 & 1320.3 \\
\hline 6 & Century Textiles \&Inds. Ltd. & 21242 & 21017.8 & 22815.6 & 24591.4 & 24930.6 \\
\hline 7 & Chettinad Cement Corpn. Pvt. Ltd. & 2419.2 & 2262.2 & 2317.4 & 2195.1 & 2452.8 \\
\hline 8 & Deccan Cements Ltd. & 604.4 & 599.2 & 541.6 & 700.7 & 758.7 \\
\hline 9 & Gujarat Sidhee Cement Ltd. & 2049.8 & 1615.1 & 1605.9 & 1477.5 & 1736 \\
\hline 10 & Heidelberg Cement India Ltd. & 4147.1 & 3430.3 & 2553.2 & 3562.5 & 3822.2 \\
\hline 11 & India Cements Ltd. & 9059 & 13478 & 14065.9 & 14420.1 & 11887.5 \\
\hline 12 & J K Lakshmi Cement Ltd. & 7653.4 & 6637.4 & 9857 & 4228 & 4535.2 \\
\hline 13 & K C P Ltd. & 1405.3 & 1775.4 & 1155 & 1248.3 & 1199.4 \\
\hline 14 & Kalyanpur Cements Ltd. & 1607.9 & 1087.2 & 1394.8 & 1394.8 & 1240.7 \\
\hline 15 & Keerthi Industries Ltd. & 307.9 & 274.6 & 236.6 & 252.2 & 238.7 \\
\hline 16 & Kesoram Industries Ltd. & 7577.1 & 7273.6 & 7195 & 13597.4 & 13494.4 \\
\hline 17 & Malabar Cements Ltd. & 1145.9 & 1031.3 & 1245.9 & 1389.1 & 1218.6 \\
\hline 18 & Mangalam Cement Ltd. & 2153.3 & 2268.1 & 2714.5 & 2769.6 & 3098.3 \\
\hline 19 & Murli Industries Ltd. & 867.9 & 1008.4 & 914.1 & 1492 & 1951.9 \\
\hline 20 & N C L Industries Ltd. & 922.1 & 1063.2 & 1063.2 & 757.2 & 738.3 \\
\hline 21 & O C L India Ltd. [Merged] & 2924.6 & 2610.3 & 3170.7 & 3284.6 & 3068.2 \\
\hline 22 & Panyam Cements \& Mineral Inds. Ltd. & 1767.5 & 1364.6 & 1039.7 & 666.1 & 724.9 \\
\hline 23 & Prism Johnson Ltd. & 1132.3 & 2897.9 & 3492.3 & 4814.3 & 4255.1 \\
\hline 24 & Ramco Cements Ltd. & 4886.7 & 5223.8 & 5180.9 & 6192.6 & 8166.6 \\
\hline 25 & Sagar Cements Ltd. & 732.6 & 668.6 & 756.5 & 948.4 & 997.6 \\
\hline 26 & Sanghi Industries Ltd. & 724.1 & 816 & 884.5 & 616 & 508.4 \\
\hline 27 & Saurashtra Cement Ltd. & 2268 & 2139.1 & 2053 & 1932.2 & 2358.4 \\
\hline 28 & Shree Cement Ltd. & 3426.3 & 4421.2 & 4844.6 & 5545.8 & 3966.9 \\
\hline 29 & Shree Digvijay Cement Co. Ltd. & 1826.2 & 2473.5 & 2607.9 & 1980.7 & 2214.5 \\
\hline 30 & Tamil Nadu Cements Corpn. Ltd. & 2492.6 & 1855.3 & 1615.8 & 1652.3 & 1578.9 \\
\hline 31 & Udaipur Cement Works Ltd. & 841.5 & 1412.6 & 1671.4 & 1918.9 & 1918.9 \\
\hline
\end{tabular}

Source: CMIE PROWESSIQ 
Table 5: Sales Revenue from 2003 to 2007

\begin{tabular}{|c|c|c|c|c|c|c|}
\hline Sr. No. & Major cement firms from 2003 to 2007 & $\begin{array}{ll}2003 \\
\text { (Rs Mn) }\end{array}$ & $\begin{array}{l}2004 \\
\text { (Rs Mn) }\end{array}$ & $\begin{array}{l}2005 \\
\text { (Rs Mn) }\end{array}$ & $\begin{array}{l}2006 \\
\text { (Rs Mn) }\end{array}$ & $\begin{array}{l}\mathbf{2 0 0 7} \\
\text { (Rs Mn) }\end{array}$ \\
\hline 1 & A C C Ltd. & 33718.8 & 39003.7 & 45498 & 37235.1 & 64680.6 \\
\hline 2 & Ambuja Cements Ltd. & 20251 & 23012.8 & 30258.4 & 70167 & 70167 \\
\hline 3 & Andhra Cements Ltd. & 1564 & 1452 & 1820.7 & 1339.4 & 5719.9 \\
\hline 4 & Anjani Portland Cement Ltd. & 383.6 & 424.9 & 482.7 & 515.8 & 890.5 \\
\hline 5 & Binani Cement Ltd. & 4418.8 & 4637 & 5301.7 & 5858.5 & 7808.5 \\
\hline 6 & Birla Corporation Ltd. & 11272.5 & 12461.3 & 13437.3 & 14238 & 17867 \\
\hline 7 & Century Textiles \&Inds. Ltd. & 25022.8 & 25713.8 & 28480.4 & 30317.7 & 35866.1 \\
\hline 8 & Chettinad Cement Corpn. Pvt. Ltd. & 3351.7 & 4122.1 & 5267.5 & 5893.6 & 8468 \\
\hline 9 & Deccan Cements Ltd. & 880.7 & 1089.8 & 1453.4 & 1701 & 2015.1 \\
\hline 10 & Gujarat Sidhee Cement Ltd. & 1758 & 1642 & 2000 & 3146 & 4383.6 \\
\hline 11 & Heidelberg Cement India Ltd. & 4457.2 & 4307 & 5034.7 & 5181.9 & 4815.2 \\
\hline 12 & India Cements Ltd. & 10271.1 & 12346.5 & 13855.9 & 18296.3 & 26131.1 \\
\hline 13 & J K Lakshmi Cement Ltd. & 6971.5 & 6971.5 & 5930.1 & 7002.1 & 9711 \\
\hline 14 & K C P Ltd. & 1330.8 & 1406.8 & 1633 & 1656.1 & 2933.5 \\
\hline 15 & Kalyanpur Cements Ltd. & 1020.4 & 727.7 & 1041.9 & 1057 & 1660.2 \\
\hline 16 & Keerthi Industries Ltd. & 87.7 & 303.3 & 496.9 & 501.8 & 820.8 \\
\hline 17 & Kesoram Industries Ltd. & 14055.3 & 15893.4 & 17288.8 & 19011 & 25400 \\
\hline 18 & Malabar Cements Ltd. & 1086.4 & 1553.9 & 1675.3 & 2278 & 2397 \\
\hline 19 & Mangalam Cement Ltd. & 2606 & 3318.7 & 3659.6 & 4973.4 & 2606.1 \\
\hline 20 & Murli Industries Ltd. & 3149.3 & 3525 & 3098.2 & 5104.6 & 5242.4 \\
\hline 21 & My Home Inds. Pvt. Ltd. & 2091.6 & 2355.2 & 2777.7 & 3512.2 & 4997.1 \\
\hline 22 & N C L Industries Ltd. & 719.4 & 713.4 & 922.4 & 1319.4 & 1802.1 \\
\hline 23 & Nirman Cements Ltd. & 66.8 & 48.4 & 20.7 & 11.1 & 23.9 \\
\hline 24 & Nuvoco Vistas Corporation Ltd. & 9186.9 & 8619.2 & 10706.3 & 13694.7 & 13694.7 \\
\hline 25 & O C L India Ltd. [Merged] & 3635.7 & 4492.8 & 5660.3 & 6933.9 & 9003.8 \\
\hline 26 & Panyam Cements \& Mineral Inds. Ltd. & 548.2 & 646.6 & 453.6 & 136.8 & 1219.3 \\
\hline 27 & Penna Cement Inds. Ltd. & 2196.4 & 3855.2 & 4526.2 & 6407.8 & 9131.3 \\
\hline 28 & Prism Johnson Ltd. & 3970.7 & 4645.1 & 5309.9 & 6792.1 & 8849.5 \\
\hline 29 & Rain Cements Ltd. & 0 & 1165.2 & 2963.7 & 3806.5 & 5644.1 \\
\hline 30 & Ramco Cements Ltd. & 7506.9 & 8451.9 & 8852.8 & 11909.7 & 18024.8 \\
\hline 31 & Sagar Cements Ltd. & 804 & 1111.8 & 1120.4 & 1537.7 & 2471.4 \\
\hline 32 & Sanghi Industries Ltd. & 508.4 & 1699.7 & 4282.1 & 6358.8 & 8614.8 \\
\hline 33 & Saurashtra Cement Ltd. & 2173.2 & 2008.8 & 2240.6 & 2794.5 & 4496.3 \\
\hline 34 & Shree Cement Ltd. & 5814.1 & 6065.1 & 7194.8 & 8211.1 & 16054.9 \\
\hline 35 & Shree Digvijay Cement Co. Ltd. & 1680.4 & 1809 & 1068.7 & 2499.7 & 2962.5 \\
\hline 36 & Tamil Nadu Cements Corpn. Ltd. & 1671.2 & 1659.6 & 1651.9 & 2013.2 & 2188.2 \\
\hline 37 & Ultratech Cement Ltd. & 0 & 26931.5 & 30579.2 & 37852.9 & 54840.4 \\
\hline 38 & Zuari Cement Ltd. & 3162.3 & 3596.6 & 4039.8 & 4738.7 & 4853.8 \\
\hline
\end{tabular}

Source: CMIE PROWESSIQ 
Table 6: Sales Revenue from 2008 to 2012

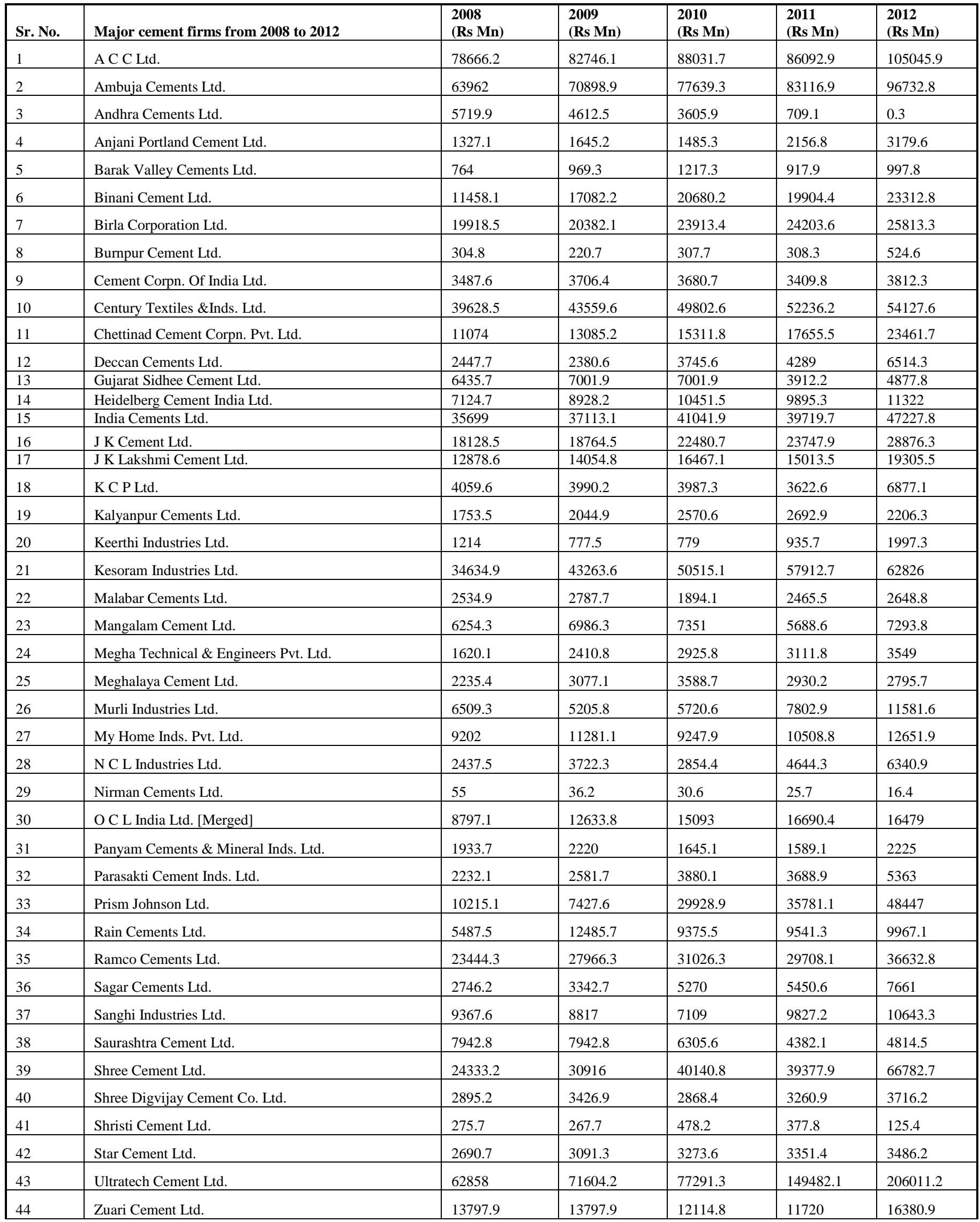


Table 7: Sales Revenue from 2013 to 2017

\begin{tabular}{|c|c|c|c|c|c|c|}
\hline $\begin{array}{l}\text { Sr. } \\
\text { No. }\end{array}$ & Major cement firms from 20013 to 2017 & $\begin{array}{l}2013 \\
\text { (Rs Mn) }\end{array}$ & $\begin{array}{l}2014 \\
\text { (Rs Mn) }\end{array}$ & $\begin{array}{l}2015 \\
\text { (Rs Mn) }\end{array}$ & $\begin{array}{l}2016 \\
\text { (Rs Mn) }\end{array}$ & $\begin{array}{l}2017 \\
\text { (Rs Mn) }\end{array}$ \\
\hline 1 & A C C Ltd. & 125071.7 & 124578.2 & 130623.3 & 132300.5 & 124338.2 \\
\hline 2 & Adhunik Cement Ltd. & 4095.7 & 4905.5 & 5035.3 & 4831.5 & 4283.2 \\
\hline 3 & Ambuja Cements Ltd. & 110053.8 & 103762.2 & 112522.1 & 107463.5 & 104629.5 \\
\hline 4 & Anjani Portland Cement Ltd. & 3110.6 & 2973.7 & 2977.2 & 3194.4 & 3601 \\
\hline 5 & Barak Valley Cements Ltd. & 1113 & 1061.8 & 1312.5 & 1110.6 & 1241.7 \\
\hline 6 & Bhilai Jaypee Cement Ltd. & 4543.9 & 7877.6 & 6895.6 & 4507.2 & 814.7 \\
\hline 7 & Binani Cement Ltd. & 25551.2 & 21191 & 19661.6 & 17645 & 15268.7 \\
\hline 8 & Birla Corporation Ltd. & 29803.2 & 34603.6 & 36753.3 & 37057.4 & 38286 \\
\hline 9 & Burnpur Cement Ltd. & 957 & 1051.2 & 885.2 & 1021.5 & 825.5 \\
\hline 10 & Calcom Cement India Ltd. & 1178.2 & 2395.5 & 3368.7 & 4277.9 & 7038.4 \\
\hline 11 & Cement Corpn. Of India Ltd. & 3285.3 & 3746 & 4629.8 & 4549.5 & 3901.8 \\
\hline 12 & Century Textiles \&Inds. Ltd. & 65868.2 & 73626.8 & 83167.7 & 86603.8 & 82295.6 \\
\hline 13 & Chettinad Cement Corpn. Pvt. Ltd. & 28161.1 & 25557.7 & 28072.3 & 27894.9 & 27823.7 \\
\hline 14 & Dalmia Cement (Bharat) Ltd. & 28029.6 & 26898.7 & 27116.8 & 29622.2 & 32009.1 \\
\hline 15 & Dalmia Cement East Ltd. & 7239 & 8545.8 & 4979.5 & 7149.5 & 9069.2 \\
\hline 16 & Deccan Cements Ltd. & 6554.2 & 4986.2 & 5729.9 & 7554.5 & 5868.3 \\
\hline 17 & Emami Cement Ltd. & 249.7 & 250.5 & 252.2 & 253.5 & 1900.5 \\
\hline 18 & Green VallieyInds. Ltd. & 1493.7 & 1535 & 2684.5 & 2724.1 & 2419.1 \\
\hline 19 & Gujarat Sidhee Cement Ltd. & 5001.6 & 4581.9 & 5451.8 & 5293.9 & 4927 \\
\hline 20 & Heidelberg Cement India Ltd. & 12769 & 15952 & 23684.8 & 19162.5 & 20021.2 \\
\hline 21 & Hills Cement Co. Ltd. & 752.5 & 298.1 & 1025.8 & 1334.1 & 1656 \\
\hline 22 & India Cements Ltd. & 52132.2 & 50345.8 & 49980.5 & 48117 & 57777.8 \\
\hline 23 & J K Cement Ltd. & 33447.1 & 32098.7 & 38738 & 41099.5 & 43747.2 \\
\hline 24 & J K Lakshmi Cement Ltd. & 23122.9 & 23005.7 & 25818.2 & 29505.9 & 32720.3 \\
\hline 25 & J S W Cement Ltd. & 7612.9 & 8330.6 & 10511.7 & 14467.9 & 16622.1 \\
\hline 26 & J U D Cements Ltd. & 1195.9 & 771.7 & 495.2 & 1036.3 & 659.5 \\
\hline 27 & K C P Ltd. & 8177 & 7340.1 & 7004.4 & 8583.2 & 9447.4 \\
\hline 28 & Kalyanpur Cements Ltd. & 3022.4 & 2644.6 & 1983.1 & 1686.3 & 777.5 \\
\hline 29 & Keerthi Industries Ltd. & 1246.7 & 1457.1 & 1758.2 & 2119.3 & 1982.8 \\
\hline 30 & Kesoram Industries Ltd. & 61653.6 & 54890.8 & 50014.3 & 46236.7 & 41396.3 \\
\hline 31 & Mangalam Cement Ltd. & 8199.8 & 8053.9 & 10533.7 & 9655.3 & 10411.7 \\
\hline 32 & My Home Inds. Pvt. Ltd. & 16954.7 & 16598.8 & 16702.3 & 15753.7 & 14587.5 \\
\hline 33 & N C L Industries Ltd. & 5309.6 & 5151.4 & 6780.7 & 8504.7 & 9845.5 \\
\hline 34 & Nuvoco Vistas Corporation Ltd. & 32160 & 39065.9 & 58515.9 & 58768.9 & 58036.3 \\
\hline 35 & O C L India Ltd. [Merged] & 20600.1 & 21053.7 & 25282.1 & 30440 & 32871.7 \\
\hline 36 & Orient Cement Ltd. & 17399.1 & 16932.7 & 18295.3 & 18014.5 & 23059.3 \\
\hline 37 & Panyam Cements \& Mineral Inds. Ltd. & 1332.2 & 618.1 & 1127 & 2733.2 & 2409.2 \\
\hline 38 & Parasakti Cement Inds. Ltd. & 4778.1 & 3846.3 & 4295.2 & 3845.6 & 3780 \\
\hline 39 & Penna Cement Inds. Ltd. & 24321.6 & 19871.9 & 22305.1 & 19366.4 & 18803.3 \\
\hline 40 & Prism Johnson Ltd. & 51494.3 & 53619 & 60243.5 & 57503.9 & 55237.7 \\
\hline 41 & Purbanchal Cement Ltd. & 1891.3 & 1837.7 & 1951.3 & 2071.8 & 2007.3 \\
\hline 42 & Rain Cements Ltd. & 10525.9 & 9782.6 & 10179.3 & 11967.2 & 10612.3 \\
\hline 43 & Ramco Cements Ltd. & 44613.9 & 43852.6 & 42451 & 42598.7 & 45848.5 \\
\hline
\end{tabular}




\begin{tabular}{|l|l|l|l|l|l|l|}
44 & Sagar Cements Ltd. & 7419.7 & 6461 & 6349.5 & 7079.6 & 6199.9 \\
\hline 45 & Sanghi Industries Ltd. & 11664.6 & 11459.9 & 10343.5 & 8400.2 & 11020.2 \\
\hline 46 & Saurashtra Cement Ltd. & 5971.5 & 5854.4 & 6294.9 & 5922.5 & 5308.8 \\
\hline 47 & Shree Cement Ltd. & 62608.7 & 66550.4 & 73474.2 & 68111.1 & 96945 \\
\hline 48 & Shree Digvijay Cement Co. Ltd. & 4293.8 & 3728.7 & 4633.5 & 5305 & 3546.2 \\
\hline 49 & Star Cement Ltd. & 3739.3 & 7570.3 & 11764.2 & 14843.3 & 13431.7 \\
\hline 50 & Udaipur Cement Works Ltd. & 318.5 & 318.5 & 1036.1 & 989.5 & 1032.7 \\
\hline 51 & Ultratech Cement Ltd. & 228574.5 & 230385.4 & 260210.7 & 267454.3 & 269644.6 \\
\hline 52 & Vadraj Cement Ltd. & 9144 & 3866.5 & 3732.8 & 224.8 & 853.5 \\
\hline 53 & Wonder Cement Ltd. & 4055.9 & 10832.1 & 11820.3 & 13875.4 & 18491.5 \\
\hline 54 & Zuari Cement Ltd. & 17984.5 & 17984.5 & 18500.6 & 19104 & 21258.7 \\
\hline
\end{tabular}

Source: CMIE PROWESSIQ

Table 8: Concentration Values

\begin{tabular}{|c|c|c|c|c|c|c|c|c|}
\hline Year & $\begin{array}{c}\text { Number of } \\
\text { cement } \\
\text { firms }\end{array}$ & CR3 & CR5 & CR10 & HHI & CCI & HTI & $\mathrm{E}$ \\
\hline 1998 & 31 & 0.368469 & 0.489323 & .7598 & 678.6997 & 0.238755 & 0.054378 & 4.563658 \\
\hline 2000 & 31 & 0.370121 & 0.503145 & .7836 & 684.0663 & 0.24018 & 0.053679 & 4.574257 \\
\hline 2001 & 31 & 0.368186 & 0.518943 & .7953 & 699.3222 & 0.243982 & 0.055716 & 4.526334 \\
\hline 2002 & 31 & 0.36865 & 0.496799 & .7873 & 681.368 & 0.242683 & 0.053114 & 4.58842 \\
\hline 2003 & 38 & 0.370621 & 0.489456 & .7449 & 662.1126 & 0.237307 & 0.052875 & 4.609937 \\
\hline 2004 & 38 & 0.346133 & 0.493072 & .7359 & 636.511 & 0.228021 & 0.052005 & 4.636726 \\
\hline 2005 & 38 & 0.342628 & 0.490103 & .7308 & 628.6855 & 0.226211 & 0.05108 & 4.663497 \\
\hline 2006 & 38 & 0.372449 & 0.498933 & .7329 & 699.4823 & 0.252393 & 0.054081 & 4.568461 \\
\hline 2007 & 38 & 0.381033 & 0.505569 & .7392 & 680.5572 & 0.232919 & 0.056113 & 4.539512 \\
\hline 2008 & 44 & 0.33797 & 0.461863 & .7033 & 592.4328 & 0.21119 & 0.051549 & 4.683435 \\
\hline 2009 & 44 & 0.338077 & 0.468391 & .6974 & 601.8194 & 0.210229 & 0.053096 & 4.646837 \\
\hline 2010 & 44 & 0.303624 & 0.428989 & .7033 & 554.3658 & 0.193682 & 0.051703 & 4.703008 \\
\hline 2011 & 44 & 0.367362 & 0.494332 & .7343 & 689.9018 & 0.248132 & 0.055834 & 4.552462 \\
\hline 2012 & 44 & 0.361293 & 0.476123 & .7418 & 679.4107 & 0.249568 & 0.05132 & 4.649348 \\
\hline 2013 & 54 & 0.354139 & 0.45226 & .6674 & 634.5387 & 0.238457 & 0.047218 & 4.763731 \\
\hline 2014 & 54 & 0.350258 & 0.45729 & .6690 & 636.1477 & 0.239239 & 0.046998 & 4.770118 \\
\hline 2015 & 54 & 0.349359 & 0.458077 & .6675 & 641.9921 & 0.241888 & 0.046328 & 4.780201 \\
\hline
\end{tabular}




\begin{tabular}{|l|l|l|l|l|l|l|l|l|}
\hline 2016 & 54 & 0.34568 & 0.451121 & .6579 & 633.585 & 0.240807 & 0.044896 & 4.815914 \\
\hline 2017 & 54 & 0.334372 & 0.454572 & .6549 & 632.6515 & 0.24185 & 0.047363 & 4.759177 \\
\hline
\end{tabular}

\section{List of Figures}

\section{CR3, CR5 \& CR10}

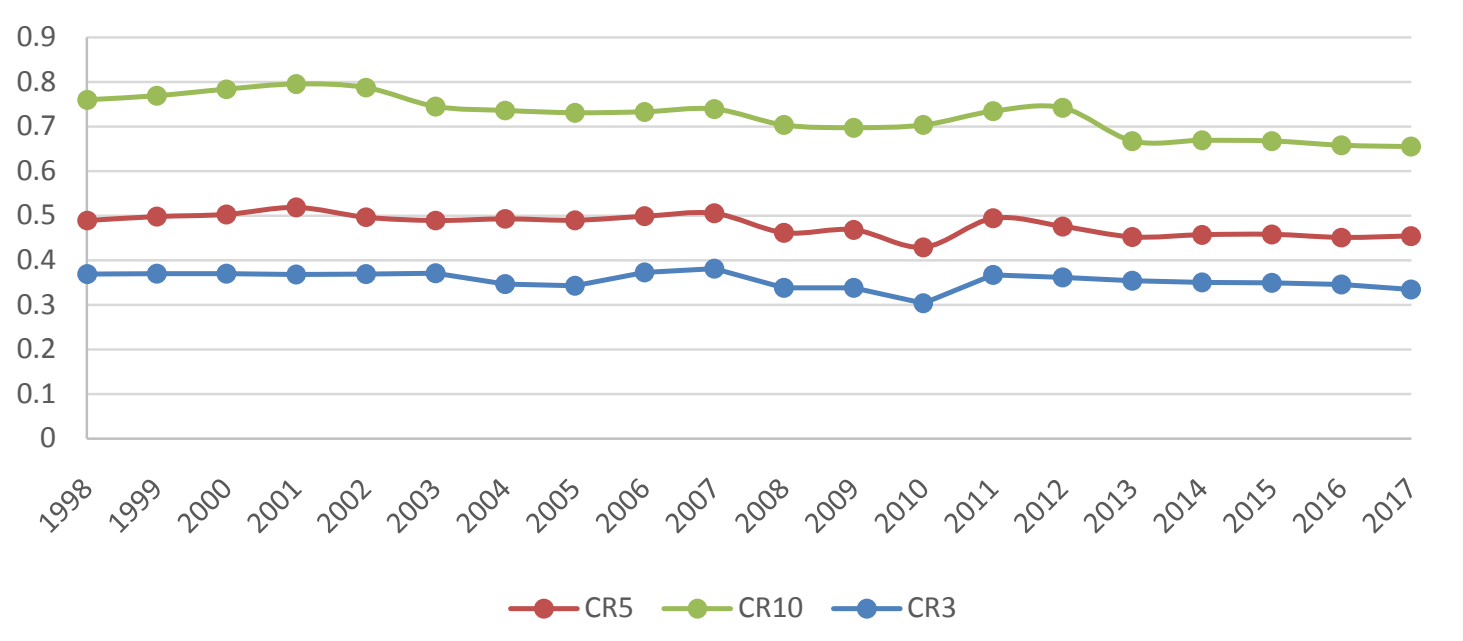

Figure1: Concentration Ratio (CRk)

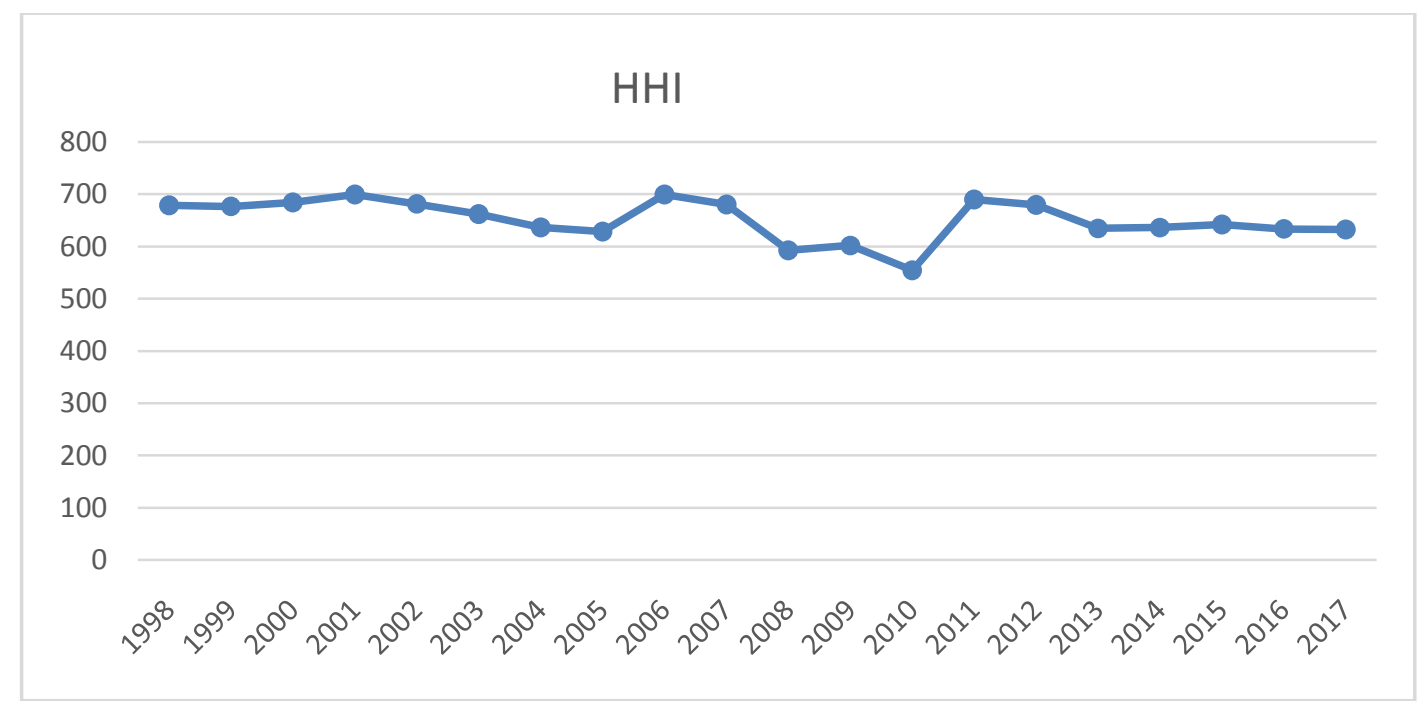

Figure 2: Herfindahl Hirschman Index (HHI) 


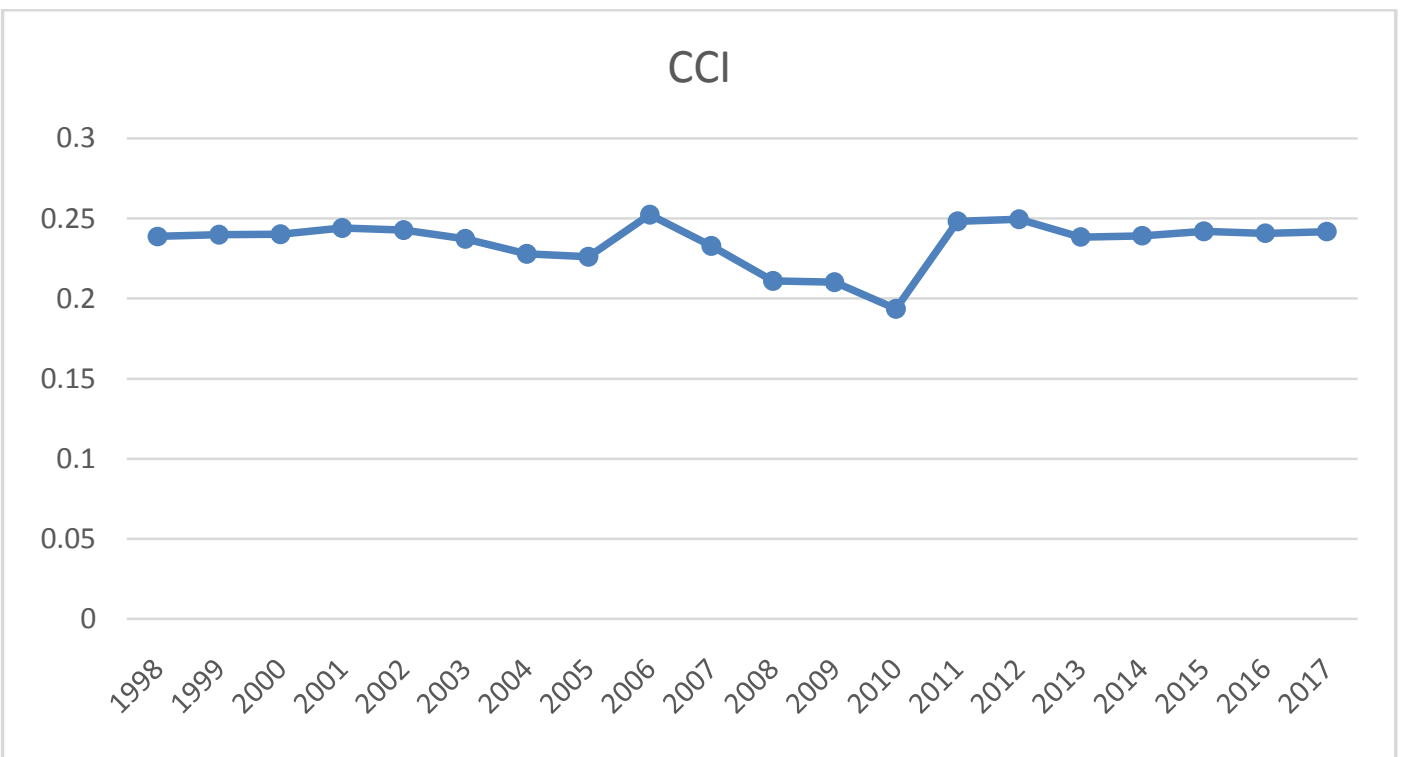

Figure 3: The Comprehensive Industrial Concentration Index (CCI)

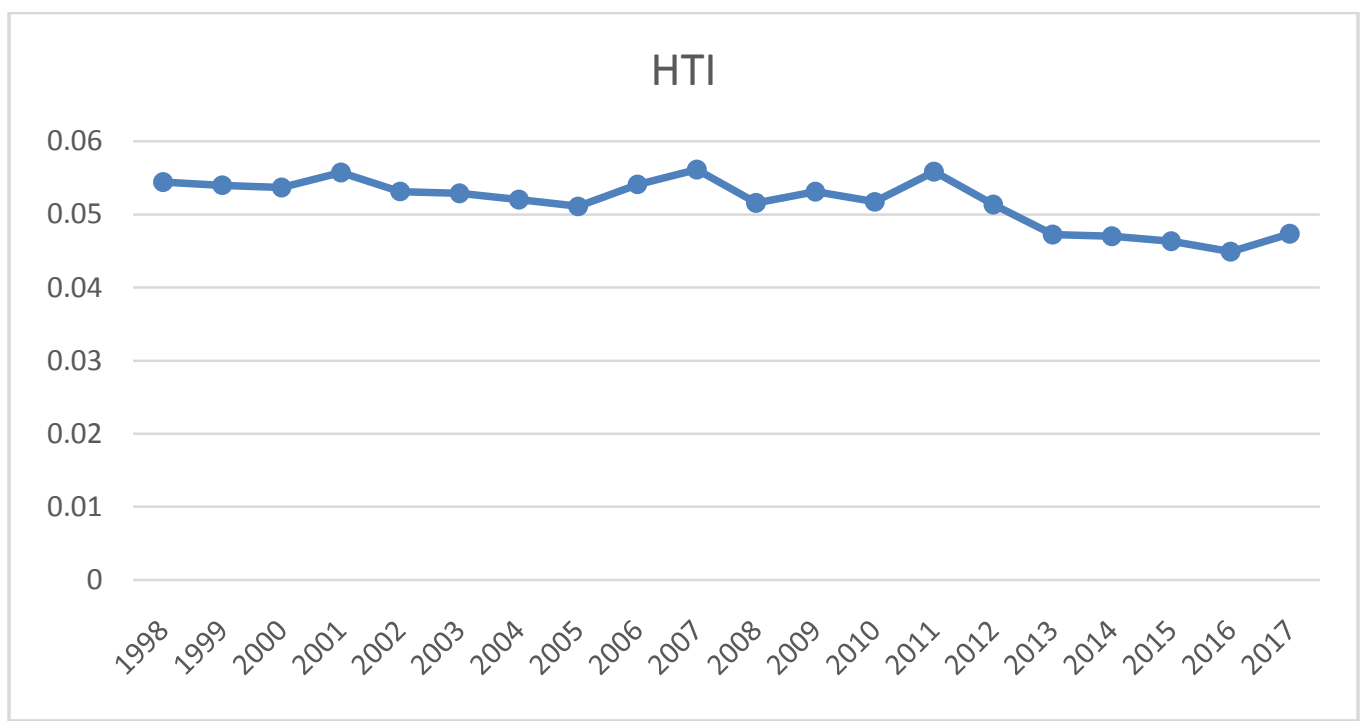

Figure 4: Hall-Tideman (1967) Index (HTI) 


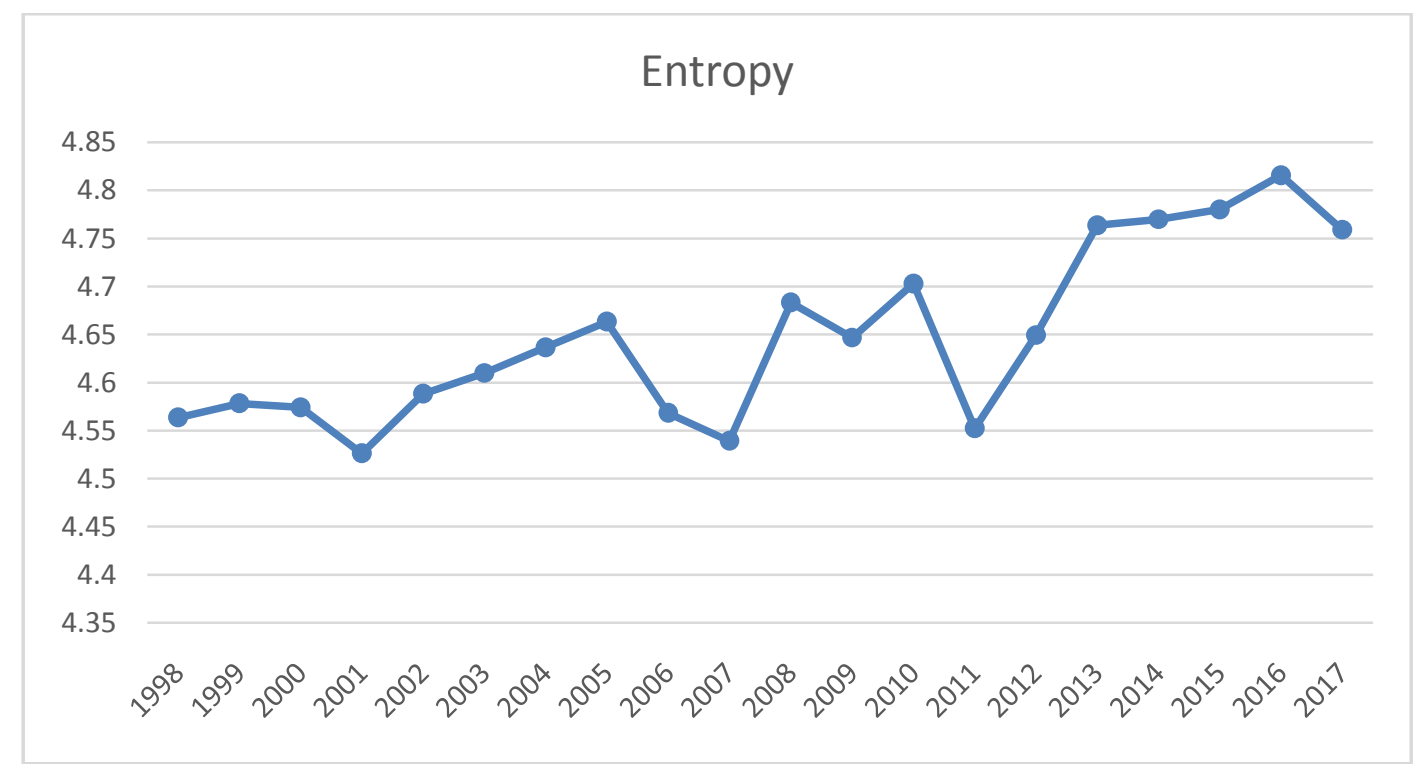

Figure 5: Entropy

\section{References}

Alhadeff, D. A. (1980). Monopoly and competition in banking. Ayer Publishing.

Alley, W. A. (1993). Collusion versus efficiency in the Japanese regional banking industry. The Economic Studies Quarterly, 44(3), 206-215.

Berger, A. N., \& Hannan, T. H. (1989). Using efficiency measures to distinguish among alternative explanations of the structure-performance relationship in banking. Managerial Finance, 23(1), 6-31.

Bikker, J. A., \& Van Leuvensteijn, M. (2008). Competition and efficiency in the Dutch life insurance industry. Applied Economics, 40(16), 2063-2084

Carroll, A. M. (1993). An empirical investigation of the structure and performance of the private workers' compensation market. Journal of Risk and Insurance, 185-207.

Curry, B., \& George, K. D. (1983). Industrial concentration: a survey. The Journal of Industrial Economics, 203-255.

Fosu, S. (2013). Banking competition in Africa: Subregional comparative studies. Emerging Markets Review, 15, 233254.

Hannan, T. H. (1991). Foundations of the structure-conduct-performance paradigm in banking. Journal of Money, Credit and Banking, 23(1), 68-84.

Jefferson, G. H., \& Rawski, T. G. (1991). Enterprise reform in Chinese industry. Journal of Economic Perspectives, 8(2), 47-70.

Krishnan, M., \&Narayanakumar, R. (2010). Structure, conduct and performance of value chain in seaweed farming in India. Agricultural Economics Research Review, 23(347-2016-16955), 505-514.

Laibuni, N. M., \&Omiti, J. M. (2014). Market Structure and Price: An empirical analysis of Irish potato markets in Kenya. Future Agricultures Consortium: Nairobi, Kenya.

Liu, D. J., Sun, C. H., \& Kaiser, H. M. (1995). Market conduct under government price intervention in the US dairy industry. Journal of Agricultural and Resource Economics, 301-315.

Lloyd-Williams, D. M., Molyneux, P., \& Thornton, J. (1994). Market structure and performance in Spanish banking. Journal of Banking \& Finance, 18(3), 433-443.

Rindyawati, Y. (2013). Partial privatization and its effect on structure, conduct, performance in the Indonesian commercial banking market. University of Canberra.

Schumacher, U. (1991). Buyer structure and seller performance in US manufacturing industries. The Review of Economics and Statistics, 73(2), 277-284.

Survey of Cement Industry \& Directory 2019, 6th Edition, Labour and Industrial Chronicle

WANG, Q. H., \& CUI, J. F. (2006). An Analysis of the Inter-bank Foreign Exchange Market in China with the SCP Paradigm [J]. Journal of Hebei University of Science and Technology (Social Sciences), 2. 